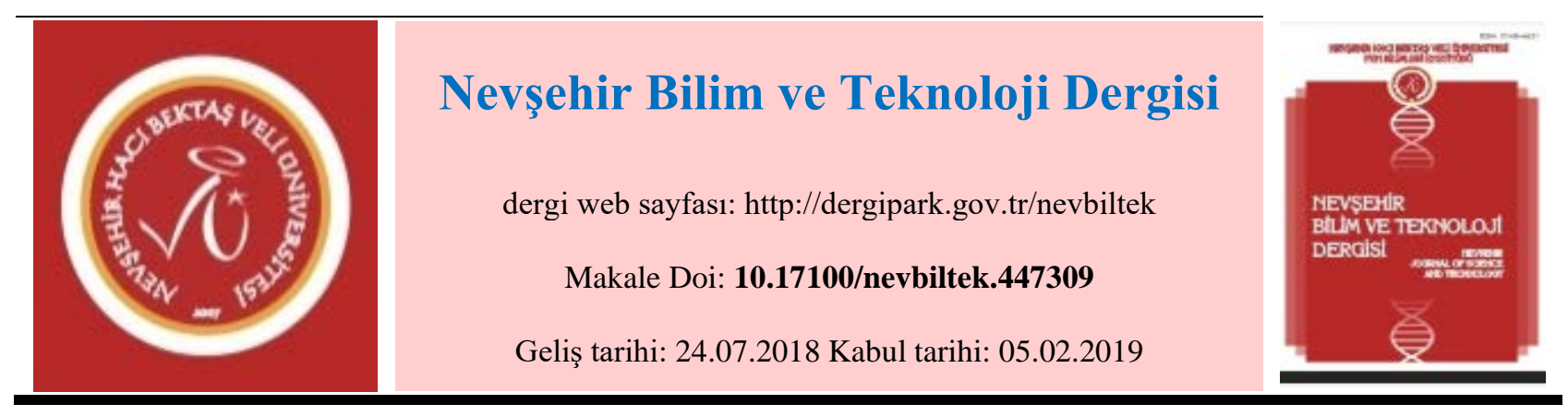

\title{
Mechanical Abrasion of Mortars Containing Clinoptilolite 1
}

\author{
Yasemin AKGÜN ${ }^{1 *}$, Ömer Fatih YAZICIOĞLU ${ }^{2}$ \\ ${ }^{1}$ Ordu University, Department of Construction, Ordu \\ ORCID ID: 0000-0002-4178-5233 \\ ${ }^{2}$ Ondokuz Mayls University, Department of Civil Engineering, Samsun
}

\begin{abstract}
In this study, it was investigated on the mechanical abrasion of mortars containing natural zeolite clinoptilolite. Bohme surface abrasion tests were carried out to cement mortar samples produced with different cement replacement ratios (0, 10, 30 and 50\%). The mechanical abrasion of mortars was determined according to TS 2824 EN 1338. The results obtained from test series were compared with each other. The abrasion of mortars containing clinoptilolite blended cement (C10) is 20.52\% less than mortars with Portland Cement (PC).

Keywords: Abrasion, Clinoptilolite, Cement Mortar, Zeolite.
\end{abstract}

\section{Klinoptilolit İçeren Harçların Mekanik Aşınması}

Öz

Çalışmada, doğal zeolit klinoptilolit içeren harçların mekanik aşınması incelenmiștir. Farklı çimento yer değiștirme oranlarıyla (\%0, \%10, \%30 ve \%50) üretilen çimento harç numuneleri üzerinde Böhme yüzey aşınma testleri gerçekleştirilmiştir. Harçların mekanik aşınması TS 2824 EN 1338 'e göre belirlenmiştir. Test serilerinden elde edilen sonuçlar birbiriyle karşılaştırılmış̧ır. Klinoptilolit katkılı çimento içeren harçların (C10) aşınması, Portland çimentolu harçlardan \%20.52 daha düşüktür.

Anahtar Kelimeler: Aşınma, Klinoptilolit, Çimento harcı, Zeolit.

\footnotetext{
${ }^{1}$ The study was presented in 1st International Technological Sciences and Design Symposium ITESDES2018 in Giresun, Turkey, 27-29 June 2018.

Sorumlu yazar e-mail: yakgun@odu.edu.tr
} 


\section{Introduction}

It is known that cement is the most used and produced building material in construction sector. The cement industry is also responsible for both the high energy use as well as about $7 \%$ of the total $\mathrm{CO}_{2}$ emissions in the world due to its production processes. For this reason, it has become quite widespread the production of blended cement by using natural or artificial pozzolanic additive material which is replaced with clinker. The application of blended cement production increases performance of mortar and concrete. At the same time, it is obtained advantages such as reducing of $\mathrm{CO}_{2}$ emissions, energy saving and economy with this applications.

Natural zeolites have recently become widely used as additive material in blended cement productions. Because, natural zeolites are pozzolanic materials containing abundant amounts of silica and alumina. When zeolite is replaced with clinker at optimum ratio, they form additional binder components by reacts with $\mathrm{Ca}(\mathrm{OH})_{2}$ which is a result of cement hydration. These additional binders improve strength and durability of mortar/concrete. Also, natural zeolites are preferred to synthetic zeolites because of their reserve and economic status.

The natural zeolites formed by the alteration of the vitric pyroclastic deposits are more reactive materials than the fly ash and furnace slags between mineral additives. Natural zeolites have reserve declared as hundred billions tons in the world [1].

Clinoptilolite is a natural pozzolan and it is one of the valuable minerals of zeolite group. The clinoptilolite is a zeolitic mineral species with chemical formula $\left(\mathrm{Na}_{3} \mathrm{~K}_{3}\right)\left(\mathrm{Al}_{6} \mathrm{Si}_{30} \mathrm{O}_{72}\right) 24 \mathrm{H}_{2} \mathrm{O}$, which is rich in silica and contains alkali and earth alkaline cations [2].

Abrasion is a physical and mechanical event that is slowly occurred. The reduction in size and mass occurred by friction of abrasive materials on surfaces of objects that make contact with each other and move relative to each other is defined as abrasion loss. Generally, the amount of abrasion depends on type of material, state of abrasion surface, friction conditions and chemical effects of environment.

As a result of optimizations carried out on all of mortar/concrete components, it is known that the abrasion resistance can be increased to desired level. Therefore, it can be possible to minimize damages caused from abrasion with increasing properly of abrasion resistance of mortar/concrete in some cases such as pavement, concrete roads, factory floor surfaces, water structures, chimneys etc.

In literature, there is a little study to examine abrasion resistance on mortar or concrete samples containing clinoptilolite [3-5]. It is always an expectation that to minimize of damage caused by abrasion as a result of increase of abrasion resistance of construction materials. Therefore, the influence of clinoptilolite on the abrasion resistance of cement mortars was investigated in this study. The abrasion tests were carried out on mortar mixtures produced with different cement replacement ratio (0,10, 30 and 50\%). And, pozzolanic activity of clinoptilolite were determined. The results are compared with each other. 
The cement used in tests is CEM I 42.5 R type of Portland cement (PC) produced in accordance with TS EN 197-1 [6]. The clinoptilolite were used as replaced material by cement. The clinoptilolite (C) that is type of natural zeolite were obtained from Manisa/Gördes regions of Turkey. The clinoptilolite samples were finely grinded in a ball mill. The amount of clinoptilolite used in mixtures were $0,10,30$ and $50 \%$ of cement weight. So, the mixtures were produced with the labels PC, C10, C30 and C50.

The CEN (The European Committee for Standardization) standard sand in accordance with EN 196-1 [7] was used in mortar mixtures. The sand-to-cement ratio is constantly 3 and water-to-cement ratio is constantly 0.5. It was used superplasticizer (at 1, 1.5 and 2\% ratios) complying with TS EN 934-2 [8] by adding to mixture water to recover of adverse effect on mortar consistency of natural zeolites in mixtures. In the production of all samples, water that does not contain organic substances and mineral salts that may be harmful is used. The flow values of mortar mixtures are about $150 \pm 20 \mathrm{~mm}$.

All mortar mixtures were prepared by applying the standard mixing, molding and curing procedures stated in TS 196-1. Samples was prepared in laboratory environment where temperatures are $20 \pm 2^{\circ} \mathrm{C}$ and relative humidity is $60 \pm 5 \%$. The samples taken from molds after 24 hours from their productions were kept in the curing tank at a temperature of 21 $\pm 1^{\circ} \mathrm{C}$ until the test days.

Chemical composition of clinoptilolite was determined by X-ray fluorescence (XRF) analysis. This analysis was carried out by using desktop XRF (EDXRF) device as percentage (\%) with loss of ignition (LOI) amount on samples prepared as pellet in laboratory of "General Directorate of Mineral Research And Explorations". X-Ray Diffraction (XRD) analysis was performed to determine mineralogical composition of clinoptilolite. This analysis was performed using a "Bruker D8 Advance”' diffractometer (with $\mathrm{Cu}_{\mathrm{K} \alpha}$-radiation and $\mathrm{Ni}$ filter) at $40 \mathrm{kV}$ and $40 \mathrm{~mA}$. The samples were scanned from $2 \theta, 2$ to $45^{\circ}$, at a scanning speed of $2 \% \mathrm{~min}$. The image for microstructure of clinoptilolite was obtained using a FEI Quanta 400 MK2 Scanning Electron Microscope (SEM).

\subsection{Test of Pozzolanic Activity}

Pozzolanic activity can be defined as the ability to react with $\mathrm{Ca}(\mathrm{OH})_{2}$ of active silica which is in the pozzolan. At the end of this reaction the amount of portlandite $\left(\mathrm{Ca}(\mathrm{OH})_{2}\right)$ is reduced, calcium silicate hydrate $(\mathrm{CSH})$ is increased.

The pozzolanic activity tests were performed on 40x40x160mm prismatic samples. In TS 25 [9], the pozzolanic activity test is defined as a characteristic determined in terms compressive strength of the mortar obtained by mixing natural pozzolan which is grinded at a certain fineness with water, standard sand and calcium hydroxide $\left(\mathrm{CaOH}_{2}\right)$. The amounts of materials required to prepare three test samples for tests on pozzolanic activity are given in Table 1. 
Nevşehir Bilim ve Teknoloji Dergisi (2019), 8(1) 63-72

Table 1. The amounts of materials for tests on pozzolanic activity.

\begin{tabular}{ccc}
\hline Materials & TS 25 & The amounts for tests \\
\hline Slaked lime $\left(\mathrm{CaOH}_{2}\right)$ & $150 \mathrm{~g}$ & $150 \mathrm{~g}$ \\
Pozzolan & $2 \times 150 \times\left(\right.$ density of pozzolan/density of $\left.\mathrm{CaOH}_{2}\right)(\mathrm{g})$ & $2 \times 150 \times(2.28 / 2.15)=318.14 \mathrm{~g}$ \\
Standard sand & $1350 \mathrm{~g}$ & $1350 \mathrm{gr}$ \\
Water & $0.5 \mathrm{x}(150+$ pozzolan $)(\mathrm{g})$ & $0.5 \times(150+318.14)=234.07 \mathrm{~g}$ \\
\hline
\end{tabular}

The moulds of the prepared samples were covered with a glass plate to prevent evaporation. The samples were allowed to stand at room temperature for 24 hours $(23 \pm 2)^{\circ} \mathrm{C}$. And then, they were left for 6 days in an drying oven at 55 $\pm 2^{\circ} \mathrm{C}$ without removing the moulds. The samples removed from the oven were left to cool until the room temperature reached. Finally, the compressive strengths of samples were performed in accordance with TS EN 196-1.

\subsection{Test of Abrasion Resistance}

Three cube moulds of $70.7 \mathrm{~mm}$ were used for each mixture in abrasion tests. The mortars were produced by using blended cements containing clinoptilolite. The abrasion losses by friction at the end of 28 days of the mortar samples were determined by Bohme surface abrasion tests in accordance with TS 2824 EN 1338 [10] (Fig. 1).

Before tests, initial volumes and initial weights of samples were determined. The abrasive force of $294 \mathrm{~N}$ was applied to samples placed on rotary disk of Bohme apparatus.

The samples were subjected to abrasive effect of $20 \mathrm{~g}$ corundum powder poured on friction path together with operation of device. Total of 16 periods that each of them is 22 cycles were applied to samples. At the end of the test (at the end of the 352 cycles), volumetric abrasion losses $(\Delta \mathrm{V})$ in samples were determined.

In calculations, it was used formula at (1) which denote $\Delta \mathrm{V}\left(\mathrm{cm}^{3} / 50 \mathrm{~cm}^{2}\right)$; volumetric abrasion loss corresponding to $\sim 50 \mathrm{~cm}^{2}$ abrasioned surfaces of samples, $\Delta \mathrm{m}(\mathrm{g})$; weight loss at end of 16 cycles, $\rho\left(\mathrm{g} / \mathrm{cm}^{3}\right)$; density.

$$
\Delta \mathrm{V}=\Delta \mathrm{m} / \rho
$$

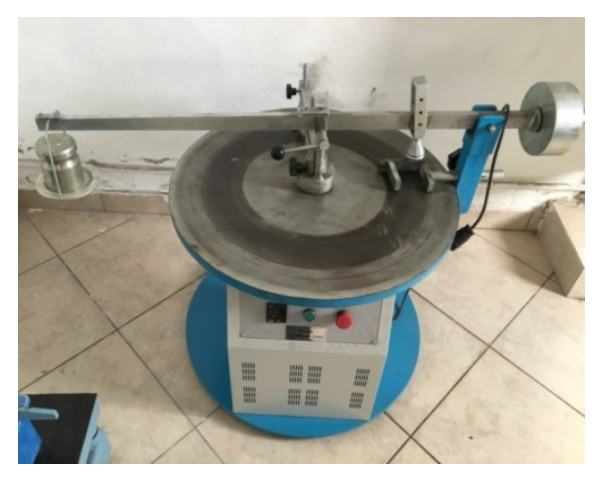

Figure 1. Bohme abrasion test device.

\section{Results and Discussion}

3.1 Some Properties of Portland Cement, Clinoptilolite and Blended Cements 
Some properties of portland cement (PC), clinoptilolite (C), blended cements (C10, C30 and C50) are presented in Tables 2, 3 and 4. Densities of clinoptilolite is 32.37\% lower than PC. Specific surface area of clinoptilolite is $27.07 \%$ higher than PC. This situation depends on mineral structure, porosity and fragilement properties of zeolite. Cumulative passing (\%) of $45 \mu \mathrm{m}$ sieve for Portland cement and clinoptilolite are 67.11\% and 68.64\%, respectively. Densities of blended cements have decreased with increasing of zeolite ratios. Fineness of blended cements containing zeolite has increased with increasing of zeolite ratios.

Table 2. Properties of portland cement (PC).

\begin{tabular}{|c|c|c|c|c|c|}
\hline \multirow{2}{*}{$\begin{array}{c}\text { Chemical composition } \\
\mathrm{SiO}_{2}\end{array}$} & \multirow{2}{*}{$\begin{array}{c}\text { (wt.\%) } \\
19.53\end{array}$} & \multicolumn{4}{|c|}{ Physical and mechanical properties of portland cement } \\
\hline & & Density, $\left(\mathrm{g} / \mathrm{cm}^{3}\right)$ & & 3.12 & \\
\hline $\mathrm{Al}_{2} \mathrm{O}_{3}$ & 5.33 & Initial set, (h) & & 2.50 & \\
\hline $\mathrm{Fe}_{2} \mathrm{O}_{3}$ & 3.56 & Final set, (h) & & 4.15 & \\
\hline $\mathrm{CaO}$ & 62.26 & Volume expansion, $\mathrm{mm}$ & & 2.00 & \\
\hline $\mathrm{MgO}$ & 0.99 & Specific surface (Blaine) $\left(\mathrm{cm}^{2} / \mathrm{g}\right)$ & & 3210 & \\
\hline $\mathrm{SO}_{3}$ & 3.02 & The compressive strengths & 2 days & 7 days & 28 days \\
\hline \multirow[t]{3}{*}{ Loss of ignition } & 3.06 & $(\mathrm{MPa})$ & 32.30 & 44.60 & 53.00 \\
\hline & & Over sieve & $45 \mu \mathrm{m}$ & $90 \mu \mathrm{m}$ & $200 \mu \mathrm{m}$ \\
\hline & & (\%) & 32.89 & 12.15 & 2.73 \\
\hline
\end{tabular}

Table 3. Properties of clinoptilolite.

\begin{tabular}{cccc}
\hline Chemical composition & Clinoptilolite (wt.\%) & \multicolumn{2}{c}{ Physical properties } \\
\hline $\mathrm{SiO}_{2}$ & 64.70 & Clinoptilolite \\
$\mathrm{Al}_{2} \mathrm{O}_{3}$ & 11.21 & Density, $\left(\mathrm{g} / \mathrm{cm}^{3}\right)$ & 2.11 \\
$\mathrm{Fe}_{2} \mathrm{O}_{3}$ & 1.38 & Blaine $\left(\mathrm{cm}^{2} / \mathrm{g}\right)$ & 4079 \\
$\mathrm{CaO}$ & 2.08 & & \\
$\mathrm{MgO}$ & 0.79 & Over sieve (\%) \\
$\mathrm{Na}_{2} \mathrm{O}$ & 0.38 & $45 \mu \mathrm{m}$ & 31.36 \\
$\mathrm{~K}_{2} \mathrm{O}$ & 3.78 & $90 \mu \mathrm{m}$ & 11.51 \\
Loss of ignition & 11.80 & $200 \mu \mathrm{m}$ & 2.57 \\
\hline
\end{tabular}


Nevşehir Bilim ve Teknoloji Dergisi (2019), 8(1) 63-72

Table 4. Properties of blended cements.

\begin{tabular}{ccccc}
\hline Physical properties & PC & C10 & C30 & C50 \\
& & & & 3664 \\
\hline Specific surface $\left(\mathrm{cm}^{2} / \mathrm{g}\right)$ (Blaine fineness) & 3210 & 3408 & & 3898 \\
Density, $\left(\mathrm{g} / \mathrm{cm}^{3}\right)$ & 3.12 & 2.75 & 2.72 & 2.46 \\
\hline
\end{tabular}

\subsection{Pozzolanic Activity of Clinoptilolite}

Pozzolanic activity of clinoptilolite are given in Table 5. According to Table 5, in TS 25, one of the conformity criterias for pozzolans is the 7 day compressive strength of samples prepared with lime-natural pozzolan mixture. The limit value of the compressive strength is at least $4 \mathrm{MPa}$. In test study performed for clinoptilolite, the average compressive strength value for the lime-zeolite (pozzolan) mixture samples was determined as 9.02 MPa. It has also been emphasized that the sum of $\mathrm{SiO}_{2}+\mathrm{Al}_{2} \mathrm{O}_{3}+\mathrm{Fe}_{2} \mathrm{O}_{3}$ in $\mathrm{TS} 25$ should be at least $70 \%$ by mass. The value of this total was found to be $77.3 \%$ for clinoptilolite. At the same time, the specific surfaces of the pozzolans should be greater than $3000 \mathrm{~cm}^{2} / \mathrm{g}$. The specific surface of pozzolan which is used in this study were found to be $4079 \mathrm{~cm}^{2} / \mathrm{g}$ for clinoptilolite (Table 3).

Table 5. Pozzolanic activity of clinoptilolite.

\begin{tabular}{cc}
\hline TS 25 limit values & Clinoptilolite \\
\hline Lime-pozzolan mixture 7 days compressive strength $>4 \mathrm{MPa}$ & $9.02 \mathrm{MPa}$ \\
$\mathrm{SiO}_{2}+\mathrm{Al}_{2} \mathrm{O}_{3}+\mathrm{Fe}_{2} \mathrm{O}_{3}$ wt. content $>\% 70$ & $\% 77.30$ \\
Specific surface area $>3000 \mathrm{~cm}^{2} / \mathrm{g}$ & $4079 \mathrm{~cm}^{2} / \mathrm{g}$ \\
\hline
\end{tabular}

In pozzolanic activity tests. Because of the specific surface of natural zeolite were below of portland cement fineness, the reaction which is between pozzolan and lime was increased. It is thought that, this situation was lead to an increment at value of pozzolanic activity. These value show that the zeolite used in study have an usability potential as a pozzolan.

\subsection{Mineralogical Composition of Clinoptilolite}




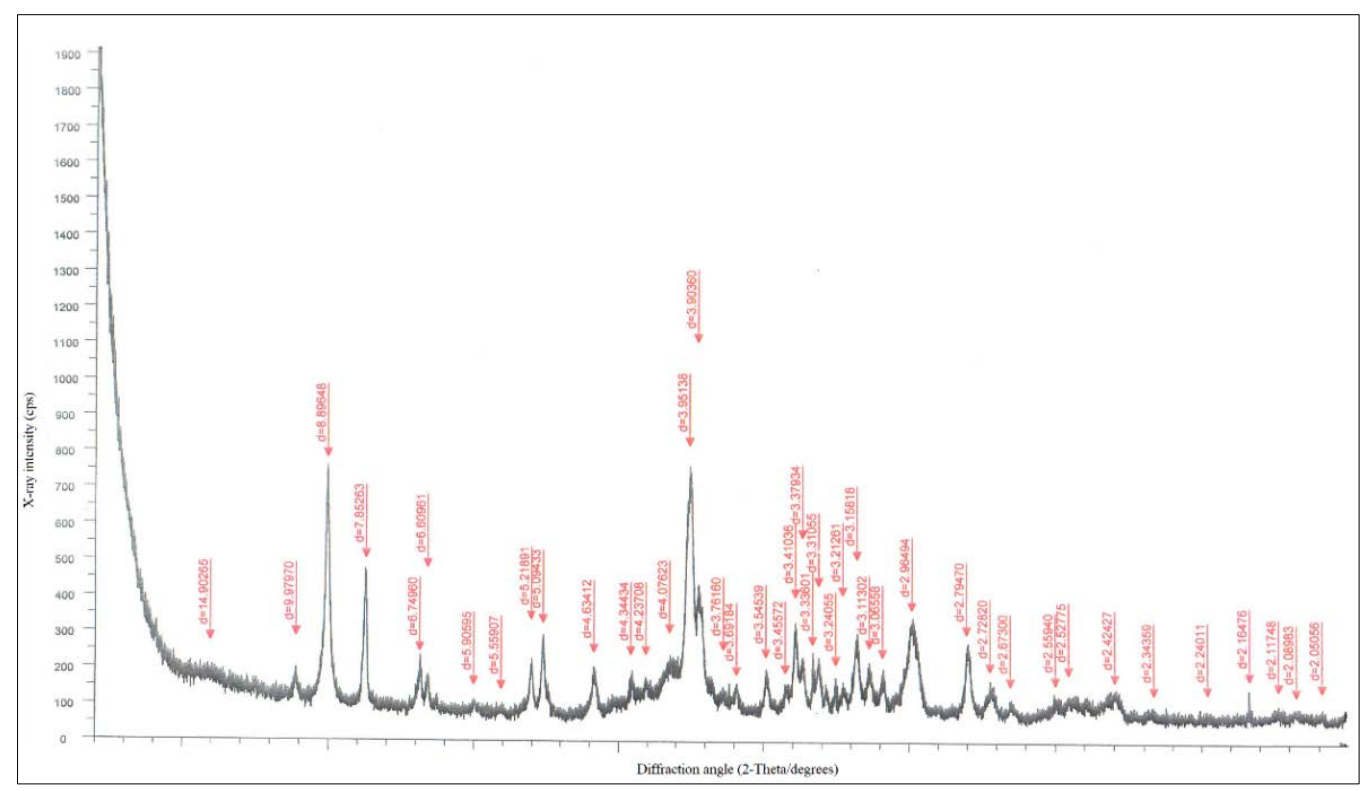

Figure 2. XRD diffraction patterns of clinoptilolite.

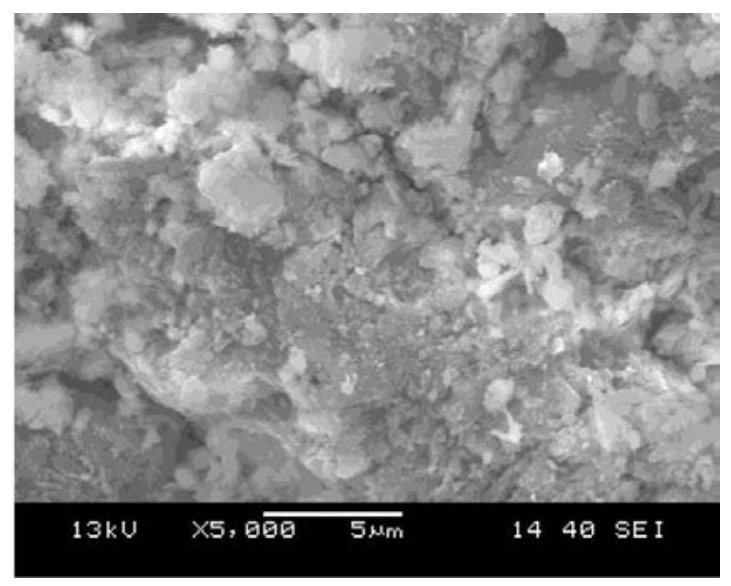

Figure 3. Scanning Electron Microscope (SEM) image of clinoptilolite sample.

XRD diffraction pattern and SEM image are presented in Figs. 2 and 3. The modal-mineralogical composition of the sample determined by XRD analysis is given below.

Clinoptilolite (Silicate - Zeolite Group Mineral) (80-85\%), Opal-CT (Opal-Kritobalite / Tridimite) (Silicate Silice Group Mineral) (10-15\%), Quartz (Silicate - Silice Group Mineral (\%<2) ), Feldspar (Na and K-Felspat) (Silicate \%Feldspate Group Mineral) $(<2 \%)$, Illite-Mica (Silicate-Clay-Mica Group Mineral) $(\%<5)$ The main component in the sample (>50\%) is "clinoptilolite" that is a zeolite group mineral and is a member of hoylandite-clinoptilolite isomorphic series. The ratio of clinoptilolite in the sample is $80-85 \%$. As other minerals; opal-CT is a certain rate, illite mica, quartz and feldspar are low and trace rates According to the mineral modal ratios at the mineralogical composition results determined by the X-ray diffraction analysis (XRD) of clinoptilolite sample, the sample is characterized by zeolite industrial raw material. When the diffractogram and SEM image of zeolite is examined, as seen that zeolite contains clinoptilolite as dominant minerals and zeolite is crystal structure. The sample confirms the requirements of national and international standards for zeolite (clinoptilolite) applications. 


\subsection{Abrasion Resistance of Mortars}

Abrasion losses $\Delta \mathrm{V}\left(\mathrm{cm}^{3} / 50 \mathrm{~cm}^{2}\right)$ are given in Table 6. Abrasion losses variations for mortars are presented in Fig. 4.

Table 6. Volumetric abrasion losses and densities of mortar.

\begin{tabular}{ccccc}
\hline Mortars & PC & C10 & C30 & C50 \\
\hline Density $\left(\mathrm{g} / \mathrm{cm}^{3}\right)$ & 2.42 & 2.14 & 2.11 & 1.91 \\
$\Delta \mathrm{V}\left(\mathrm{cm}^{3} / 50 \mathrm{~cm}^{2}\right)$ & 11.84 & 9.41 & 10.27 & 11.62 \\
\hline
\end{tabular}

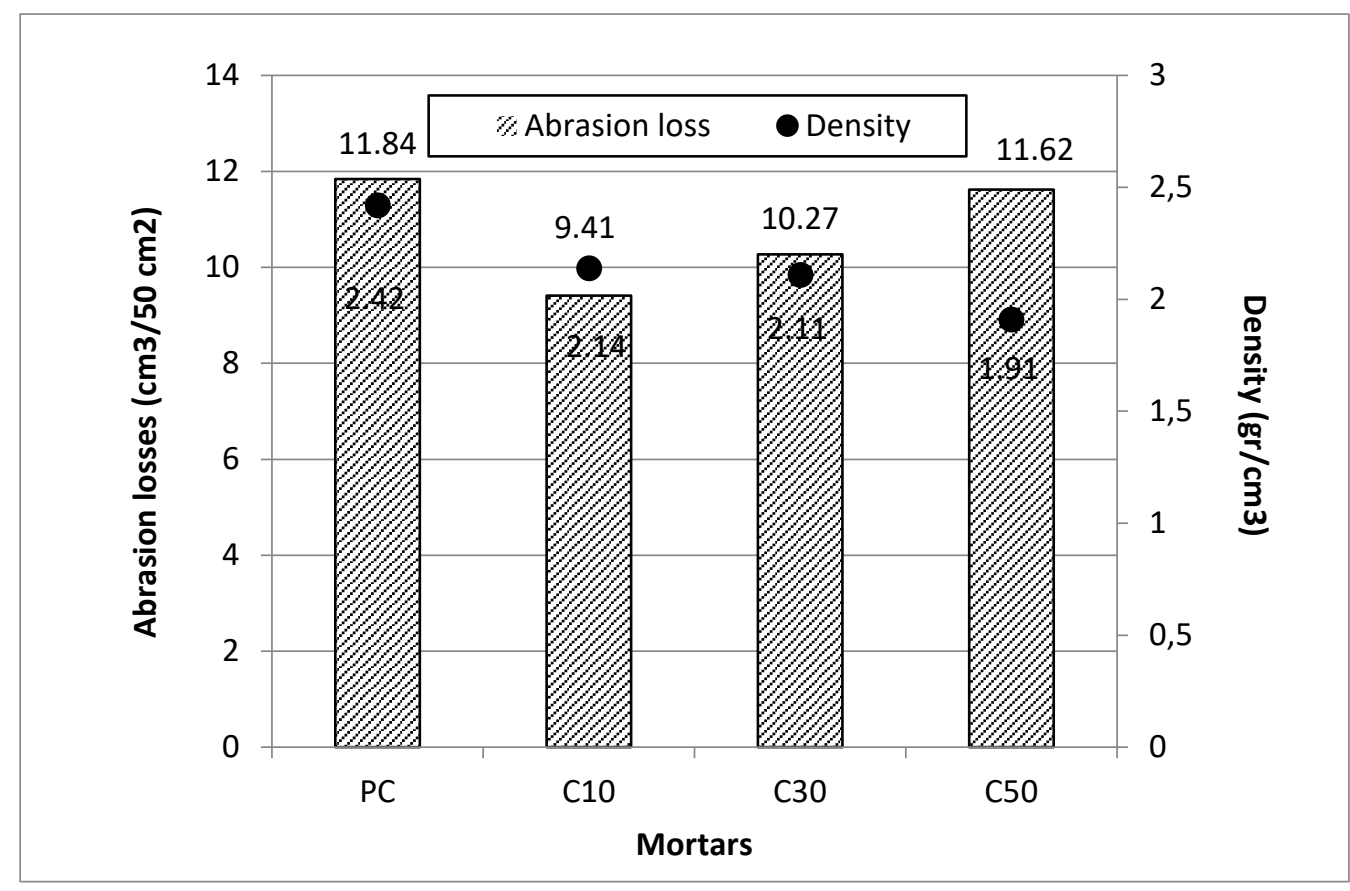

Figure 4. Abrasion loss and density variation for mortars.

The volumetric abrasion losses for mortars with blended cements containing clinoptilolite (C10, C30 and C50) were $20.52 \%, 13.26 \%$ and $1.86 \%$ less than mortars with PC, respectively. In other words, it has been found that the abrasion losses of mortars with blended cement are less than mortars with PC for all replacement ratios. This positive effect in abrasion resistance is probably performance increasing occurred at aggregate-cement paste interface and cement paste due to pozzolanic reactions of zeolite. Also, as clinoptilolite replacement ratio increases, the densities of mortars decrease.

\section{Conclusions}

1. Since the density of clinoptilolite is lower than that of Portland cement, the densities of mortars produced by blended cement containing clinoptilolite are less than that of mortars produced by Portland cement. 
2. The properties of natural zeolite clinoptilolite investigated in this study such as pozzolanic activity, mineralogical structure, high silica-alumina content, high specific surface, low density are sufficient for sustainable blended cement productions.

3. The abrasion losses of mortars containing clinoptilolite were lower than that of mortars containing portland cement for all replacement ratios.

4. A larger number of studies should be carried on zeolites named clinoptilolite obtained from different regions to reduce amount of cement and to improve of cement performance.

\section{Acknowledgment}

This study was funded by the Scientific Research Project Unit of Ordu University under Project No: TF-1521. Also, we would like to thanks to Gördes Zeolite Company for their support and assistance.

\section{References}

[1] Chan S. Y. N. and Ji X., "Comparative study of the initial surface absorption and chloride diffusion of high performance zeolite, silica fume and PFA concretes” Cement Concrete Comp., 21, 293-300, 1999

[2] Özen, S., Göncüoğlu, M. C., Liguori, B., Gennaro, B., Cappelletti, P., Gatt, G. D., Iucolano, F., and Colella, C., "A comprehensive evaluation of sedimentary zeolites from Turkey as pozzolanic addition of cement- and limebased binders”, Construction and Building Materials, 105, 46-61, 2016

[3] Bilim, C., "Zeolit Katkısının Harçların Aşınma Direncine Etkisi”, 6th International Advanced Technologies Symposium (IATS'11), Elazığ, Turkey, 2011

[4] Gabriel C., Rajwant S. B., Yushan Y., and Junlan W., "Zeolite as a wear-resistant coating”, Microporous and Mesoporous Materials, 151, 346-351, 2012

[5] Akgün, Y., and Yazıcıoğlu, Ö. F., “İki Farklı Doğal Zeolit Katkısının Çimento Harç Aşınma Dayanımına Etkisi”, Ordu Üniversitesi Bilim ve Teknoloji Dergisi, Cilt:6, Sayı:1, 94-104, 2016

[6] TS EN 197-1, (2002). Çimento - Bölüm 1: Genel Çimentolar- Bileşim, Özellikler ve Uygunluk Kriterleri. Ankara: Türk Standartları Enstitüsü.

[7] TS EN 196-1, (2009). Çimento Deney Metotları - Bölüm 1: Dayanım Tayini. Ankara: Türk Standartları Enstitüsü.

[8] TS EN 934-2, (2013). Kimyasal Katkılar - Beton, Harç ve Şerbet için - Bölüm 2: Beton Kimyasal Katkıları Tarifler, Gerekler, Uygunluk, İşaretleme ve Etiketleme, Ankara: Türk Standartları Enstitüsü.

[9] TS 25, (2008). Doğal Puzolan (Tras)-Çimento ve Betonda Kullanılan-Tarifler, Gerekler ve Uygunluk Kriterleri. Ankara: Türk Standartları Enstitüsü.

[10] TS 2824 EN 1338, (2005), Zemin Döşemesi için Beton Kaplama Blokları-Gerekli Şartlar ve Deney Metotları. Ankara: Türk Standartları Enstitüsü. 


\section{Genişletilmiş Özet}

Giriş: İnşaat sektöründe en çok kullanılan yapı malzemesinin çimento olduğu bilinmektedir. Çimento aynı zamanda üretim işlemleri gereği hem yüksek enerji kullanımından hem de dünya toplam $\mathrm{CO}_{2}$ emisyonlarının yaklaşık \%7' sinden sorumludur. Bu nedenle günümüzde klinker ile yer değiştirmeli doğal veya yapay katkı malzemeleri kullanarak katkılı çimento üretmek oldukça yaygınlaşmaktadır. Katkılı çimento uygulaması, harç ve betonun performansını da artırmaktadır. Aynı zamanda, bu uygulama ile $\mathrm{CO}_{2}$ emisyonlarının azalması, enerji tasarrufu ve ekonomi gibi avantajlar elde edilir. Doğal zeolitler, son zamanlarda katkılı çimento üretimlerinde katkı malzemesi olarak yaygın bir şekilde kullanılmaktadır. Çünkü, doğal zeolitler bol miktarda silisyum dioksit ve alümina içeren puzolanik malzemelerdir. Zeolit belirli oranlarda klinker ile yer değiştirdiğinde, puzolanik özelliği gereği, çimentonun hidratasyonu sonucu meydana gelen $\mathrm{Ca}(\mathrm{OH})_{2}$ ile reaksiyona girerek ilave bağlayıcı bileşenler meydana getirirler. Bu ilave bağlayıcılar harç ve betonun dayanım ve dayanıklılığını iyileştirir. Doğal zeolitler, sentetik zeolitlere rezerv ve ekonomik olma durumları nedeniyle tercih edilirler. Klinoptilolit, doğal puzolandır ve zeolit grubunun değerli minerallerinden biri olarak anılır. Aşınma ise, yavaş meydana gelen fiziksel ve mekanik bir olaydır. Harç ve beton bileşenlerinin tümü üzerinde yapılan optimizasyonların bir sonucu olarak, aşınma direnci arzulanan seviyeye çıkartılabilir. Böylelikle, beton yollar, fabrika taban yüzeyleri, su yapıları, bacalar gibi bazı yapılarda harç ve betonun aşınma direncinin artmasıyla aşınmanın neden olduğu hasarları minimize etmek mümkün olabilir. Literatürde, klinoptilolit içeren katkılı çimento kullanılarak üretilen harç ve beton numuneler üzerinde aşınma direnci incelemeleri çok az sayıdadır. Yapı malzemelerinin aşınma dirençlerinin artmasının bir sonucu olarak aşınmanın sebep olduğu zararın minimize edilmesi daima arzu edilen bir durumdur. Bu çalışmada, klinoptilolit içeren katkılı çimento kullanılarak üretilen harç numunelerin aşınma dirençleri incelenmiştir. Yöntem: Çalışma konusu klinoptilolit, Türkiye' nin Manisa ili, Gördes ilçesinden standardına uygun incelikte Gördes Zeolite A.Ş. tarafından öğütülmüş olarak temin edilmiştir. Harç numunelerin hazırlanmasında kullanılan malzemelerin tanımlanması için XRF (X-Rays Fluorescence Spectrometer), XRD (X-Ray Diffraction) ve SEM (Scanning Electron Microscope) inceleme yöntemleri kullanılmıştır. Doğal zeolitin puzolanik aktivitesi TS25' e uygun olarak belirlenmiştir. Aşınma testleri farklı çimento yer değiştirme oranlarıyla (\%0, \%10, \%30 ve \%50) üretilen harç karışımlar üzerinde gerçekleştirilmiştir. Aşınma direnci deneylerinde 70,7 mm boyutlu küp kalıplar kullanılarak üretilen harç numunelerin 28 gün sonundaki sürtünmeli hacimsel aşınma kayıpları Böhme yüzey aşınma test yöntemi ile belirlenmiştir. Deney serilerinden elde edilen sonuçlar, birbirleriyle karşılaştırma yöntemi kullanılarak irdelenmiştir. Sonuçlar ve Tartışma: Klinoptilolitin yoğunluğu, Portland çimentosundan \%32,70 daha düşük, özgül yüzey alanı ise \%27,07 daha yüksektir. Çimentodaki zeolit katkı oranının artmasıyla katkılı çimentoların yoğunlukları azalmakta, incelikleri artmaktadır. T25' deki puzolanlar için uygunluk kriterleri gereği, kireç-doğal puzolan karışımıyla hazırlanan numunelerin 7 günlük basınç dayanımı en az $4 \mathrm{MPa}$, özgül yüzey alanının $3000 \mathrm{~cm}^{2} / g$ ' dan daha yüksek ve içeriğindeki $\mathrm{SiO}_{2}+\mathrm{Al}_{2} \mathrm{O}_{3}+\mathrm{Fe}_{2} \mathrm{O}_{3}$ toplamının kütlece en az \%70 olması gerekmektedir. Klinoptilolitin basınç dayanımına bağlı puzolanik aktivitesi 9,02 MPa' dır. Özgül yüzey alanı $4079 \mathrm{~cm}^{2} / g$ ve $\mathrm{SiO}_{2}+\mathrm{Al}_{2} \mathrm{O}_{3}+\mathrm{Fe}_{2} \mathrm{O}_{3}$ toplamı kütlece \%77,30’ tür. Bunlara göre çalışmada incelenen doğal zeolit klinoptilolit, puzolanik aktivitesi, mineralojik yapısı, yüksek silisyum dioksit- alümina içeriği, yüksek özgül yüzeyi, düşük yoğunluğu gibi özellikleri ile sürdürülebilir katkılı çimento üretimleri için uygun özellikler taşımaktadır. Puzolanik aktivite testlerinde doğal zeolitin (klinoptilolit) özgül yüzey alanının portland çimentosu inceliğinin altında olması nedeniyle kireç ve puzolan arasındaki reaksiyonu artırmıştır. Bu durum puzolanik aktivitenin değerinde bir artışa neden olmuştur. Buna göre, çalışmada kullanılan doğal zeolit puzolan olarak kullanılabilir potansiyele sahiptir. Klinoptilolit içeren katkılı çimento kullanılarak üretilen harçların (C10, C30 ve C50) hacimsel aşınma kayıpları, portland çimentosu kullanılarak üretilen harçlarınkine (PC) göre sırasıyla \%20,52, \%13,26 ve \%1,86 olmak üzere daha azdır. Aşınma direncindeki bu pozitif etki, muhtemelen zeolitin puzolanik reksiyonları sayesinde, çimento hamuru ve agregaçimento hamuru ara yüzeyinde meydana gelen performans artışıdır. Aynı zamanda, klinoptilolit yer değiştirme oranı arttıkça harçların yoğunlukları düşmektedir. Sonuç olarak; bu çalışmada, klinoptilolit katkı içeren katkılı çimento kullanılarak üretilen harçların aşınma dirençlerinin \%30 katkı oranına kadar arttı̆̆ 1 görülmektedir. 